\title{
Ideology and Strategy. German Africa Policy and Its Critics
}

By Volker Weyel

\section{A Century ago: Colonial Policy and Criticism of Colonialism}

"Fortunate negroes! First they will corrupt you by making you get used to European needs, then they'll buy your land for a song, and finally, you'll be trained to work and how! The urge of our bourgeoisie to spread civilisation truly is a splendid thing. ... But we can already imagine the call: 'Damn your civilisation, you profiteers! " " The whole civilisation campaign of the Congo Conference was aimed at "replacing open slavery by disguised slavery". ${ }^{1}$ In early December, 1884 , shortly after the opening of the meeting by the 'Iron Chancellor' in Berlin, this could be read in the central organ of German social democracy, which could only reach Germany illegally by way of the 'Red Forces' Postal Service, having been printed in Zurich. This was due to the 'Socialist Act passed in 1878 to oppress the workers' movement.

In another social democratic polemic appearing outside the German Reich against the colonial policy of the country, which was then getting underway, Jens Lauris Christensen remarked after the event:

"In the entire history of the world, I would not know where to find an instance of seizing other people's property without any formalities that would in any way be comparable to the outcome of the Congo Conference. ${ }^{2}$

He also examined the

"real meaning of the phrase that the European countries are bringing civilisation to the savage tribes. All the culture that they have got from us consists almost entirely of us letting them toil and slave away for our benefit, that we steal their land, and, as a sign of gratitude, that we infect them with spirits and syphilis. ${ }^{3}$

A remarkably clear-sighted critique of colonialism that was already voiced by contemporaries of the Berlin Conference, and not by historians assessing things later on.

The opposition German colonial expansionists faced at times could reach from the workers' movement right through bourgeois liberalism to Bismarck (who did not want colonial adventures to jeopardize foreign relations) and those that would have liked to

1 Der Sozialdemokrat, No. 49, 4 December 1884, p. 3.

2 Christensen, Jens L(auris), Gegen unsere Kolonialpolitik. Ein ruhiges Wort in bewegter Zeit, Zürich 1885, p. $28 \mathrm{f}$.

3 Op. cit., p. $26 \mathrm{f}$. 
start colonizing the Balkans and "round of ${ }^{4}$ the Reich on its own continent. Many of those then speaking out against colonialism in Germany (and also in other European countries) were only ranticolonialists in inverted commas; however, being tied to specific interests, they regarded themselves as down-to-earth realists. Many an argument would arise precisely from feeling apprehensive about the profitability of the venture as such and its becoming a burden on the taxpayer' (which meant the bourgeois who did not immediately profit from colonial trade).

Bourgeois-accountant calculating also continued to mark colonial criticism of that force in imperial Germany that posed the most determined opposition to its political and economic system: German social democracy. Christensen also pointed out that positive effects would probably not materialize, and that one would have to reckon with entanglements with (European) rivals which would ultimately threaten (European) peace.

(Christensen was not one of the most prominent representatives of the workers' movement; but his fate was typical of those suffered through the Socialist Act. The teacher and writer, born in 1856 in Ruttebüll, had participated in unmasking a police informer, was then banned from staying in Berlin in 1886, chased through Germany, and finally escaped persecution by emigrating to America, where he became an executive of the 'Chicagoer Arbeiter Zeitung (Chicago Workers' Newspaper). He was also acquainted with inner-party controversies; his resolute left-wing views caused the, albeit incorrect, suspicion to arise among comrades that he was an anarchist.)

The Congo Conference itself never played an independent role in the social democratic debate and agitation. This was not true for the discussion on the packet boat subvention, a long-forgotten dispute that ran parallel to the Conference. The Reichstag debate on financial support for packet boats to East Asia (with a subsequent branch to Zanzibar), which had been applied for by the government, also became an endurance test for the Social Democrat Reichstag Party - whose majority initially supported the subvention -, and finally for relations between the Reichstag Party and the editors of the party central organ then in exile. Here, it is only of interest to note that, already at the time of the Congo Conference, a dilemma arose from this issue - which has to be seen in the context of colonial expansion - that only became really clear in later years. This is how the historian Franz Mehring assessed the situation in his Party History of the beginning of this century:

"A party as eminently devoted to civilisation as social democracy has every reason to tend the seeds of civilisation that can already germinate in the soil of bourgeois society; since all these seeds have been capitalistically infected in this society, it is often difficult to determine the right boundary between capitalist interests and the

4 Loehnis, H., Die Europäischen Kolonieen. Beiträge zur Kritik der deutschen Kolonialprojekte, Bonn 1881, passim. 
interest to spread civilisation; it was not easy to recognize in the case of the packet boat subvention. " ${ }^{5}$

The contradiction already contained in essence in colonial criticism of $1884 / 85$ can only be clarified by looking beyond that period. One can observe in the period prior to the First World War that the critical orientation towards colonialism was maintained: however, a closer examination of the contents of this criticism and the conception of the world and history does seem appropriate.

In his extensive survey on 'Socialism and Imperialism', Hans-Christoph Schröder points out that "the principal objections of social democracy to colonial policy" appear as a "catalogue of free-trade liberal complaints". ${ }^{6}$ The fundamental critique of the capitalist system that was trying to prolong its historically overdue existence through colonial expansion, and to export the social question ' away, was expressed in its most concrete form in profitability and advantage considerations. And also, after the crude methods of ruling in the colonies had become known, in humanitarian objections. According to Schröder, this taking up of the positive traditions of the bourgeoisie, from which it had partly turned away in the course of the beneficial Wilhelminian upturn, was also linked with the fact that "specific socialist criteria to judge colonial policy did not exist". ${ }^{7}$ At any rate, it became clear that classical Marxism contained a certain area of conflict: elucidating (but not simply transferable to the new forms of colonial expansion) analysis of primitive accumulation, taking sides with the oppressed and exploited classes on the one hand - a teleology of progress, and, in accordance with this, low regard for obsolete, dying out social formations on the other hand. However, revolutionary socialists also assigned ssavages' encountered abroad to the latter. Against this background, the attitude towards the colonial peoples' right of self-determination appears to be somewhat ambiguous. Understanding was shown for the resistance of these peoples, but a connecting line was not drawn between those that were faced with the same system both here and abroad; the party theoretician Karl Kautsky denied (at the turn of the century) that "the struggles of savages against civilisation are our struggles". ${ }^{8}$ A direct convergence with state colonial policy developed hand in hand with the general adaptation of the majority of the party to existing conditions and the increasing influence of reformists and revisionists. With the votes of the majority social democrats, but against those of the Independents (USPD) - who had evolved from the opposition against the imperialist war -, the Weimar National Assembly demanded the return of German colonial possession as League of Nations mandates on March 1, 1919. ${ }^{9}$ However, the end of German colonial history had already been reached.

To return to its origin: 1884 was not only the opening year of the Berlin Conference;

5 Mehring, Franz, Geschichte der deutschen Sozialdemokratie. Zweiter Teil, Berlin (East)' 1960, p. 619.

Schröder, Hans-Christoph, Sozialismus und Imperialismus. Teil I, Hannover 1968, p. 142.

Op. cit., loc. cit.

Quoted in op. cit., p. 163.

See op. cit., p. 198 
before that it had already become the foundation year of the German colonial empire. Social democracy orientated towards revolution was a persecuted movement with relatively little influence on the public at the time; however, a detailed examination of its position was necessary because this movement represented the most resolute critique of capitalism, while, at the same time, it bore certain ambiguities regarding the colonial issue. And this party also continued to set an example for the international labour movement (of the industrialised world). But who represented that part of the public that was enthusiastic about colonialism? The historian Fritz Ferdinand Müller locates the mass basis of the German colonial movement in the chauvinist middle classes, which had been shaken by the crises of 1873 and 1882 . However, as soon as conquest ventures proved to be profitable, petty bourgeois investors of 'colonial companies' like the 'German/East African Company felt cheated: in 1885 it was a

"typical middle-class company. ... Its development during the following years once again showed that in German colonial policy the middle classes only paved the way for finance capital, and even here they only played a very modest role" ${ }^{10}$

In 1887 it already "passed into the hands of high finance"." ${ }^{11}$

The growing camp of the colonial movement also contained most of the Christian missionary societies; voicing a criticism of methods or certain details, the courageous way in which individual missionaries stood up for the interests of the 'natives do not in any way refute these general observations, which incidentally do not only hold for Germany.

\section{One Hundred Years after the Berlin Conference: Two Ways of Assessing Things}

\section{Cause for Celebration?}

It took more than a quarter of a year - November 15, 1884, to February 26, 1885 before the 'General Act' of the Berlin Conference was passed. The contemporary public did not take too much notice of the conference; of course it was recorded by historians, but hardly any special literature on the subject was published. The division of Africa was not carried out during the conference; however, rules were set up for "new seizures along the coasts", and, bilaterally and outside the formal framework of the conference, claims were clarified. Later on, too, bilateral agreements and conflicts were to play by far the more important role - for instance, the 'Krüger Dispatch of the Emperor (congratulating on the repelling of the Jameson Raid' by the Boers) in 1896 in the German-British relations, or the Fashoda Crisis of 1898 in Franco-British relations.

10 Müller, Fritz Ferdinand, Deutschland - Zanzibar - Ostaf rika. Geschichte einer deutschen Kolonialeroberung 1884-1890, Berlin (East) 1959, p. 150.

11 Op. cit., p. 174. 
Ultimately, the struggle of the big powers for the spheres of interest was to shift away from Africa to the Pacific. According to the historian Helmut Bley, ${ }^{12}$ against this background, the Berlin Conference seems to have been more of symbolic than of real importance. However, the symbolic value really is enormous: The Berlin Conference stands for the foreign dominance of Africa and its people - ultimately implemented and maintained by force. An event of this kind can hardly be regarded as a cause for celebration after one hundred years, and there seems to be just as little ground to celebrate the hundredth anniversary of the founding of German colonial rule in South West Africa (today's Namibia), Togo, and the Cameroons. But these events certainly do provide food for thought, and they call for a critical assessment of circumstances.

Bonn's official foreign policy has thought it wiser to practically ignore these commemorative events. However, committed scientists, journalists and publishers have taken up the issue, and also various people in the developmental policy scene, which is partly located outside the 'system's public'. (There are several 'Thirdı and 'One World' groups that are at the most loosely connected, and they usually reject state developmental policy or at least regard it very sceptically.) In the other German state, the German Democratic Republic, an international scientific conference was held in Berlin (East) from February 6-8, 1985, on the topic 'Colonialism, Neocolonialism, and Africa's Path into a Peaceful Futurer. Since my essay deals mainly with the Federal Republic in view of its international economic and political importance, it must suffice to mention here that serious scientific criticism (not only the agitative kind) of colonialism had already been formulated in the GDR when ex-Nazi colonial apologetes like Wahrhold Drascher were still thriving publicly ${ }^{13}$ in the Federal Republic. Above all, Fritz Ferdinand Müller's book on the 'German East Africar colonial conquest ought to be mentioned. It was published in 1959 and has already been cited above. However, it is also worth noting that Müller commenced a longer stay in Africa after the book had appeared, and he did not subsequently return to the GDR. GDR science would hardly maintain a leading role in German language criticism of imperialism, for since 1968, varied appropriate literature, albeit not of uniform quality, has developed in West Germany. And its freedom of critique is not limited by an understanding of science of the Soviet type.

\section{A productive controversy in Hanover}

The subject of the Association for African Studies' 1984 annual meeting, which took place in Hanover from June 13-16, is representative of an approach predominant among critical scientists: 1884-1984: One Hundred Years of Intervention in Africar. The IVereinigung von Afrikanisten in Deutschland (VAD) is a scientific society with a political stance. Its way of dealing with the issue, which does not only dissect historical colo-

12 Interview with Professor Bley on 17 July 1984.

13 See Vorwärts, 18 September 1963, p. 19, review article by Imanuel Geiss. 
nialism tamely but also covers the different types of contemporary intervention in Africa (a far more daring venture), has by no means been commonly accepted by the public. Rather, Professor Bley of the VAD executive drew the sobering conclusion that "active and positive" engagement in, and the immediate influencing of, official Africa policy was hardly feasible, that this society would hardly be affected. However, he combined this with the statement that under given circumstances, the primary task to be tackled must be participating in a long-term changing of consciousness. In view of the evolving renewed increase in Euro- and ethnocentric attitudes in assessing situations - against a background of growing economic and psychological uncertainty -, and even the danger of a resurgence of racist interpretation patterns, committed scientists have once again realized the necessity of dismantling the scolonial legend and to counteract the new evolving of such legends. For, as Frank Gatter of the 'Bremen Africa Archive', which also participated in the organization of the meeting, remarked appropriately, the "decolonization of consciousness" is far from having been accomplished.

The conception of the meeting makes it clear that tendencies towards a resignative attitude can also be opposed under more difficult general conditions. It had probably never before been achieved at a comparable conference in the Federal Republic to reach such a high degree of African participation - students, scientists, representatives of liberation movements; the clearly welcomed participation of so many students, both German and African, was a result of the annual meeting not being conceived as a purely academic conference.

The sections of the meeting dealt with the following topics: '1884 - A New Colonial Order?; ' Colonialism and Labour'; 'African Reactions'; 'Violations - Culture and Colonialism'; 'Mission and Colonialism'; 'Hunger and Colonialism'. So, an assessment of colonial influence and its consequences was at issue. The participants were in the main certainly immune to an apologetical "This way and that way" that holds "the positive phenomena" to be "a permanent basis for present economic relations and creates harmless continuity". For an audience critical of imperialism, however, Helmut Bley's warning of a contrary assessment making things idyllic (which is widespread among the progressive 'scene') does seem most appropriate:

"In accordance with the European tradition critical of its own culture, the destructiveness of the colonial impact is contrasted with the idyll of the socially harmonic and materially secured precolonial African world. ${ }^{14}$

Indeed, a simplifying of matters is just as unsuitable as an over-identification; neither of the ways can supply appropriate instructions for action.

Controversies arose mainly from the discussion on present internal conflicts in African society. Whereas experts on African studies who regarded themselves as progressive used to be somewhat hesitant in tackling such topics, internal structures are now being more frequently examined. Just how tricky this still seems to be was experienced by some lecturers who were subjected to the criticism of both German and African partici- 
pants. Of course Europeans addressing themselves to the internal African class situation is problematical, as this can only too easily have the effect of a diversionary manoeuvre, a cover-up of the prevalent state of dependence. However, one should not avoid this discussion. The organisers remarked self-critically that the world economic and political general framework within which class division takes place should have been defined more clearly.

Apart from the fact that these differences of opinion did not determine the general course of the meeting, I regard this controversy as quite productive. The fact that a criticism of dealing with internal conflicts of African society often dissolved into extremely general (and repetitious) discussions on colonialism and global concepts of imperialist exploitation does demonstrate how important a micro-analysis is. At any rate, the specific interests of classes and strata supporting puppet regimes may have consolidated themselves to such a degree that some interventions would no longer prove to be effective. Even an Idi Amin enjoyed a certain international scope of action. A product of classical colonialism and a bizarre representative of neocolonial contradictions, in spite of all his nationalistic bragging, he was extremely dependent on foreign countries (for instance in supplying his army), but he was also able to switch alliances within a day's notice.

\section{A paralyzing understanding in Lomé}

There was no lack of pleasantly sounding reasoning among the colonial expansionists of yore; in practice, the cultural mission occasionally shrank to a quest for markets for German spirits. At the turn of the century, an army surgeon and opponent of alcohol complained that the respective German trade links "with Togo were the cause for the seizure " ${ }^{15}$ This actually took place according to a completely familiar pattern on the grounds of a 'contract' presented to a 'king' of dubious authority on July 5, 1884.

Hardly anything could illustrate the Hanover call for a "de-colonization of consciousness" better than the fact that, in July 1984, "the Celebration of the 100th Anniversary of German/Togolese Relations" actually took place in Lomé, and the speech held by the president of the Bundesrat then in office - according to protocol among the four leading representatives of the Federal Republic of Germany - was printed in an of ficial government bulletin and headed " 100 Years of German/Togolese Friendship ". ${ }^{16}$ Incidentally, the Togolese President had initiated this show.

To avoid being tempted to include satirical traits in the description of an event that was of serious intent, a detailed description of what went on in Lomé is presented below from an official point of view:

15 Matthaei, (Paul), Der Alkohol als Störenfried in den Kolonien und daheim, Leipzig 1900, p. 3.

16 Bulletin, No. 86, 14 July 1984, p. 761. 
"The Togolese recall the epoch" of German protectorate "with such pleasure that they have made a public celebration out of the 100th anniversary of the signing of the contract. On this occasion, the President of the Bundesrat and Bavarian Chief Minister Franz Josef Strauß, who enjoys especially friendly links with the President of Togo, Gnassingbe Eyadema (in office since 1967), and Siegfried Lengl, State Secretary of the Federal Ministry for Economic Cooperation, visited the Togolese capital Lomé.

They brought a special present with them: A treaty signed on July 5 confirms that the Federal Republic of Germany has released Togo from debts ensuing from financial cooperation and totalling 288 mio. DM. Furthermore, Bonn presented 20 lorries and other vehicles urgently needed by the country. "17

This recapitulation of Franz Josef Strauß's speech in Lomé is representative of the widespread attitude towards the colonial era that was described in Hanover as an "apologetic 'this way and that way'u:

"For sure, the era of German protectorate has also been critically judged. No doubt, mistakes were also made in this era. But a historical assessment would reveal that the accomplishments of the missionaries, businessmen, governors, and their officials have been appreciated. "18

Despite the fact that a Minister of State in the Foreign Affairs Ministry had to deliver a speech at a Bonn ceremony to mark the "100th Anniversary of German/Togolese Relations ", ${ }^{19}$ it must be pointed out that this special relation with Togo is not so much a West German/Togolese one, but rather reflects a specifically Bavarian/Togolese link. Closely connected with the ruling Christian Social Union (CSU) in the Bavarian Free State, the Hanns Seidel Foundation is particularly active in Togo (but also in Zaire). The economic interests, which also play a role, are by no means those of German big industry, but rather those of some middle-class entrepreneurs. But even the cruellest mocker must appreciate that the level of economic interaction is much more advanced now than it was in 1884: Prussian potato spirits are no longer exported to the Togolese coast, instead a Bavarian has established the beer brewery 'Benin in the country itself ... ${ }^{20}$

17 Informationsdienst Entwicklungspolitik, No. 7/84, 31 July 1984, p. 1.

18 Op. cit. (Footnote 16), p. 762.

19 Bulletin, No. 128, 30 October 1984, p. 1133.

20 Frankfurter Rundschau, 12 July 1984, p. 3, article by Ulla Schickling. 


\section{Bonn's Africa Policy: Buyers, Suppliers, Recipients}

\section{Aid, not trade?}

The celebrations in Lomé are interesting as regards the conception of history and the world of the participants; they are only to a certain degree representative of the general Africa policy of the Federal Republic of Germany. Also, the former German colonies do not play a dominating role in private investments and foreign trade links; a Soviet author remarked in 1979:

"In 1977, the proportion of the former German colonies in the total commodity turnover of the FRG with the states of Africa amounted to 3 per cent. $"{ }^{21}$

Before Bonn's Africa policy is examined more closely, the terms of reference ought to be clarified. The 'Southern' policy is often characterized by the term 'world-wide interdependencer. We do not have to bother with a critique of this; it is all too obvious who has the say in the (actually existing) network of international economic relations, who plays the role of the donor' in 'development issues', and who is the rrecipient?.

But this already leads to the question what 'development assistancer actually means. The obvious answer for radical critics - to simply comprehend it as a form of neocolonialism - is not sufficient. (This already becomes clear through the fact that, on an international scale, even the sharpest opponents of imperialism sometimes criticize the withholding or reduction of raid - of course, this process above all illustrates the degree of dependency of states that also claim to have chosen their own course in the framework of ostensibly interdependent international relations). Whereas the motivation is obvious in the case of trade, capital export, and private direct investments - profit and revenue -, it is more difficult to penetrate the jungle of ideology, real concern, and even varying political reasoning as far as public (and also private) development assistance is concerned. It is the latter category that is more important in the context of the Federal Republic's relations with most of the African states. Africa's role as a purchaser of West German products is really quite modest; the continent's share of total West German exports dropped from $6.3 \%$ in $1981^{22}$ to $3.8 \%$ in 1985 . Since quite some time the bulk of West German Africa business has been transacted with five countries only: Algeria, Egypt, Libya, Nigeria - all four being petroleum producers - and South Africa. In 1985 these countries accounted for more than seven tenths of all West German exports to Africa: South Africa (24.6\%), Egypt (15.5\%), Algeria (14.2\%), Nigeria (9.3\%) and Libya $(7.6 \%) .{ }^{23}$ Imports from Africa have also dropped during the last few years - Africa's share of total West German imports "fell from a peak of $7.8 \%$ in 1980 to $6.0 \%$ in

21 IPW Berichte, No. 10/79, p. 60, article by Sergej Nikolajew.

22 Hofmeier, Rolf, West Germany's Policy in Africa. A New Bonn Government: Continuity and Change, in: Legum, Colin (ed.), Africa Contemporary Record 1983-84 (Vol. 16), p. A241.

23 Based on Afrika-Verein e.V., Tätigkeitsbericht 1985, Hamburg 1986, p. 1-5. 
$1983 \lll{ }^{24}$ The portion was only slightly increased in 1984 and 1985 , representing $6.1 \%$ and $6.2 \%$ respectively. The five countries constituting the front row of the Federal Republic's customers do also lead the ranks of her suppliers, their shares adding up to almost three quarters of West German imports from Africa in 1985: Nigeria (22\%), Libya (21.8\%), Algeria (14.3\%), South Africa (11\%) and Egypt (5.5\%). ${ }^{25}$

But 'development aid' can also be immediately profitable for the 'donor' country - this can hardly be denied in view of the following calculation set up by Bonn's Federal Ministry for Economic Cooperation (BMZ): The sum of orders for German industry that resulted from bi- and above all multilateral development cooperation clearly exceeds the efforts on the part of the Federal Republic of Germany in bi- and multilateral assistance - by about 15 per cent. In argumenting publicly, this result of a model calculation ends up in maintaining that for every DM 1,- ) aid, DM 1,15 flowed back to the country; in this way, the native public, by now bothered by economic problems, should be convinced of the usefulness of raid, and the ideological basis of solidarity and 'partnership' should be transformed to 'self-interest'. Consequently, the new basic policy document on development issues ('Guidelines') which was approved by the Federal Government on March 19, 1986, does not dwell on trifles such as international solidarity'. Instead, the Minister responsible uses his introduction to the document in order to underline West German self-interest and to focus on the "employment-effectiveness", i. e., on the benefits "for our economy and our labour force". ${ }^{26}$

In spite of this official emphasis on immediate interests, this is not the quintessence of state development policy of the Federal Republic and the West as a whole: Rather, the creation of conditions to permanently integrate the states of the South into the existing system of international political and economic relations is at issue (and also the prevention of any deviation). Pursuing this general objective does, however, also imply that the relation "DM 1,- to DM 1,15" cannot hold for the individual case - states and also groups of states! The fact that direct profit interest does not have to be the decisive factor for rassistancer in a concrete case makes quite clear why the Western governments enjoy such large scopes of action in Africa, and it also explains the efforts of African governments to obtain raidr.

\section{Between Hallstein Doctrine and New International Economic Order}

The role the industrial state Federal Republic of Germany plays as a medium-sized power and 'donor' for Africa had certainly not been fully recognized when relations with the new' states of Africa were established. In 1960, when 16 African states became

24 See Fn. 22.

25 See Fn. 23.

26 Bundesministerium für wirtschaf tliche Zusammenarbeit (ed.), Grundlinien der Entwicklungspolitik der Bundesregierung, Bonn 1986, p. 7. 
formally independent at once and were admitted to the United Nations, the Federal Republic had been formally sovereign as regards internal and foreign policy for just five years (and the two German states were only able to join the world organization 13 years later). At that time, Bonn's policy towards Africa was of a low key type; the main political thrust was directed to securing Western integration of the Federal Republic. A low profile was maintained out of consideration towards those Western powers that were still immediate colonial powers or wished to retain their special position in the young' states. Even today, one still keeps fairly clear of the French 'chasse gardéer, the privileged hunting grounds of French capital. Political gains are still regarded suspiciously by the French ally; it is worth noting that Guy Penne, then President Mitterand's expert on African affairs, also came to attend the dubious 1984 German/Togolese celebration (and Washington sent its special envoy Keese).

On a bilateral level, Bonn's relations with African capitals were determined initially and for a long time by the so-called Hallstein Doctrine, implying that establishing diplomatic links with the German Democratic Republic meant that Bonn immediately broke its links. Even after the relation of the two states in Germany had been fixed by the Basic Treaty signed on December 21, 1972, and the subsequent international recognition of the GDR, the urge remained to recognize certain fundamental political positions of Bonn in the form of the 'Berlin Clauser (which implies the including of the Land Berlin, i. e., Berlin (West), within the validity of bilateral agreements).

Im 1960, 'Africa Year', the Federal Government had found in the loss' of the colonies a fact which was almost unanimously deplored by the political forces of 1919 - an apparently especially favourable starting point for its policy towards colonial countries that just had obtained independence. It could be disregarded that the Reich Governments of the Weimar Republic had tacitly retained their ambition to recover colonial possessions. ${ }^{27}$ The heritage of the 'Third Reich', which burdened relations with East European countries and the West, hardly had a negative effect on relations with the states of Africa (or Asia and Latin America). Often (and this could well still be the case), the name Hitler did not imply colonial expansion (which, however, was practised in Europe itself) and racist measures up to the millionfold systematical liquidation of those of a different kind, but rather stands for the wartime opponent of the colonial masters - a point of view which could be characterized as a sort of digressive anti-imperialism. For the African states the colonial innocencer maintained by the Germans was ultimately hardly relevant, but the Federal Republic for them became useful in the course of the diversification of their foreign relations, after all, Africa was aiming at achieving a kind of counterbalance to the still dominating former colonial masters and also the influence of the super-powers. This 'bonus' of a medium-size power not so much geared to attaining

27 Mulumbar Rwankote, Mathias, Ostafrika in den Zielvorstellungen der Reichspolitik und der verschiedenen Interessengruppen im Rahmen der kolonialen politischen Aktivitäten in der Zeit der Weimarer Republik, Diss. Köln 1983, p. 202. 
influence was, according to Helmut Bley, "soon to be forfeited due to four circumstances":

- The Hallstein Doctrine meant that the East/West problem was extended into Africa after all;

- Being committed to the Western Alliance, Bonn got caught in the slipstream of criticism of the leading Western power's Vietnam war as well as of the colonial war of the NATO partner Portugal;

- Economic, political, military, and cultural cooperation with racist minority régimes in Southern Africa shook Bonn's credibility;

- "With the advent of international criticism of the world economic system, the second largest foreign trade nation came into the centre of criticism anyway. ${ }^{28}$

Even though some of the items of this catalogue lost importance, especially during the social-liberal era, two central issues arising from West German/African relations remained (and still do remain) open:

- on a global political scale the (good) economic and (certainly somewhat cooled down) political relations between the Federal Republic and South Africa;

- on a global economic scale the debate on the New International Economic Order. These two complexes were also mainly picked up by the progressive critics of the Social and Free Democrat (SPD/FDP) Coalition's Africa policy. The Coalition's period of office was, however, divided into two phases: the first act of doing away with antiquated policies, played against the background of favourable economic conditions (1969-1973), and the second act of austerity measures and mere administration, provoked by crisisstricken economic development (1974-1982). Accordingly, emphasis was shifted: During the first phase, one managed to a certain degree to get away from the

"instrumentalisation of development aid as a means of German re-unification policy and global system competition",

as Franz Nuscheler puts it; now

"West Germany's own objectives were not given up, but, rather, integrated in a long-term conception of the international development of industrial and developing countries. " 29

In the economic crisis, the immediate objectives of the Federal Republic reappeared more distinctly; in the United Nations arena, Bonn presented itself as an especially persistent advocate of a if ree' world economy, and an opponent of the concept of a New International Economic Order. It was a social-liberal government that joined forces with the United States (whose President was not yet Ronald Reagan) and Great Britain at the 11 th United Nations General Assembly Special Session in the late summer of 1980 to arrange an industrial nations hardliner's thwarting of 'global negotiations'.

29 Nuscheler, Franz, Partnerschaft oder Ausbeutung? Die Entwicklungspolitik der sozial-liberalen Koalition, in: Grube, Frank and Gerhard Richter (eds.), Der SPD-Staat, München 1977, p. 326, 329. 
('Global negotiations' were conceived as a general debate on all issues arising from matters concerning North/South relations; Western industrial nations feared that in this context their predominance in the IMF and the World Bank Group could become affected.)

A 'Memorandum' of German experts on Africa, comprising 33 propositions and printed in a paperback edited by the historian Helmut Bley and the political scientist Rainer Tetzlaff in 1978, also belonged to the second phase of the social-liberal era. ${ }^{30}$ As regards the policy towards South Africa, a peaceful, non-violent strategy, which the Federal Government regarded as the only way of social change that was acceptable and worthy of support, was uncovered as a means of actually stabilising the status quo; the oppressed certainly ought to have a "right of resistance ". ${ }^{31}$ An imposition of mandatory United Nations sanctions on Pretoria (a refusal to grant credits, a suspension of investments, an oil embargo) was explicitly advocated. The danger of over-reacting to Soviet Africa policy was pointed out; as regards Bonn's development policy it was felt that

"development aid (should) not be beneficial to the privileged upper classes in the respective receiving countries in a disproportionate way ". ${ }^{32}$

Also, it should "not be a reward for politically friendly régimes " ${ }^{33}$ Even a more or less reformist programme like the 133 Propositions` was not destined to have any permanent effect on the policy of a government led by social democracy.

This already allows the assumption that the Africa policy of a government led by the Christian Democratic Union (CDU) by no means had to imply completely breaking with that of its predecessor, especially since the former (FDP) Foreign Affairs Minister returned to office after the fall of the SPD Chancellor in October 1982. Quite significantly, the policy towards Africa was exclusively thematicised as regards Southern Africa in the "Suggestions for a New German Foreign Policy towards Africa, AsiaPacific, and Latin America" presented by the Konrad Adenauer Foundation, which is close to the CDU, shortly after the Federal elections on March 6, 1983, which the CDU had won:

"As an element of the free West and a member of NATO, the Federal Republic must concentrate on keeping South Africa in the Western camp. . . . German investments in this country are considerable. Hitherto, this fact has often been withheld in a somewhat ashamed way ....134

This means that once more, the South Africa policy has become a touchstone for Africa policy in general.

Africa policy, which had always been measured by progressive critics against the peace-

30 Helmut Bley and Rainer Tetzlaff (eds.), Afrika und Bonn. Versäumnisse und Zwänge deutscher Afrika-Politik, Reinbek 1978.

31 Op. cit., p. 292.

32 Op. cit., p. 296.

33 Op. cit., p. 297.

34 IIS-Auslands-Informationen, No. 06/83, 29 March 1983, p. 14. 
policy claim of the government and had usually been found to be too easy, now faces criiticism from the right, which is also not new, but far more weighty. For these despisers are not standing in front of the doors of power, they are within the government camp itself. $^{35}$ Their concepts, i. e., the Africa policy ideas of the CSU (or, to be more exact, their chairman) and the right wing of the CDU, have so far not become of ficial foreign policy; but one must certainly reckon with them. Dealing with Africa primarily in terms of the East/West conflict, 'security policy' (both in a military and geostrategical sense), and securing raw materials is quite characteristic of this approach, and this also holds for the result of the ranalysis', which regularly implies the demand of approaching Pretoria. This concept is for instance contained in the essays "Africa - Europe's Achilles heel?" of Lt.-Gen. (ret.) Vogel, and "Southern Africa and German Security" of Rear Admiral (ret.) Poser, who had been in a leading position in the military intelligence of the Bundeswehr and the NATO up to $1973 .{ }^{36}$ They were edited in 1980 by the 'Deutsche Afrika-Stiftung' (DAS, German Africa Foundation); this establishment of Bonn CDU/CSU right-wingers had evolved in 1978 against the background of political developments in and around Namibia in order to support the forces of the 'Turnhalle Alliancer in 'Südwest', and to promote relations with conservative African governments. The DAS took over the monthly 'Afrika-Post', formerly the mouthpiece of the pro-Pretoria 'German/South African Society،.

\section{Recent Trends}

Against the background of right-wing criticism, Foreign Affairs Minister Hans-Dietrich Genscher made use of the opportunity of the 20th anniversary of the OAU's foundation in May 1983 to give a speech on fundamental principles to African ambassadors. He defined the following basic points of the Federal Government's Africa policy: a policy for peace, non-use of force, the promotion of "genuine" non-alignment, supporting measures to stabilize Africa, emphasising the right of self-determination. ${ }^{37}$ The latter issue also included reference to the participation of Bonn in the Namibia initiative of five Western powers, which had already been launched in 1977, but whose performance rather serves to confirm sceptics.

As regards Africa policy, the Foreign Affairs Minister (who was the major proponent of the rchanger towards a CDU-dominated government) ironically embodies the element of continuity, whereas the head of the BMZ, who is responsible for Bonn's 'Official Development Assistancer (ODA), personifies the 'changer. So it seems appropriate to examine

35 For details on intra- and inter-party controversies after the 1982 change of government, see Hofmeier (Fn. 22).

36 Vogel, Uwe and Günter Poser, Afrika und deutsche Sicherheit, Bonn 1980.

37 Auswärtiges Amt (ed.), Dritte Welt. Materialien zur Politik der Bundesrepublik Deutschland, Bonn 1984 (third revised impression), p. 74 f. For extracts from the speech in English, see Hofmeier (Fn. 22), p. A $229 \mathrm{f}$. 
both his development policy approach in general and his position on Africa. Minister Jürgen Warnke (CSU) takes the credit for practising a development policy without a guilty conscience: Two interviews include the identical formulation that the new government has freed this policy "from a guilty conscience", that it has "relaxed its approach and freed it from ideology ". ${ }^{38}$

"Development aid has a moral root, but it must not be confused with a kind of compensation commitment for the sins of the colonial era. $1{ }^{39}$

As regards "Africa, that causes us the greatest anxiety", it is stated that "much was caused by external circumstances, ... (but) that much was also due to the political deviations of these countries themselves". The status of the Federal Republic's own objectives is once more enhanced; moreover, the heading rrelaxing' yields instructive information: During the SPD era, there was "loud talk about development aid without ties", but the partners had been given necessary instructions "on the occasion of intergovernmental negotiations during coffee and cognac breaks". The question whether a decision is taken on "aid for a country according to its needs or its political orientation" is also clearly answered: "Whoever kicks us on the shin cannot expect to be a favoured partner of ours ${ }^{40}{ }^{40}$

It could be disputed whether the explications of political orientation of the Minister describe a comprehensive 'changer (this would probably apply most appropriately to the position on Central America), or whether they do not merely mark the contours of a policy that has hitherto been practised in principle. At any rate, he is in the current mainstream of Western development policy in general. The scarcity of means and general raid fatiguer on the side of the 'donors' have led to the ruling élites of Africa coming into the focus of criticism as well, the World Bank and the IMF urging for structural adjustment measures, the European Community imposing a spolicy dialoguer on its 'partners' in Africa, the Caribbean, and the Pacific. The tendency to impose conditions is by no means confined to the phenomenon of ties to raid ' deliveries.

The clarifications of the Minister - merely recognizing a moral (i. e., by no means binding) commitment to resource transfer, linking raid ' with export promotion, a renewal of using the East/West conflict as a political gauge - certainly remain valid beyond the development policy of the Federal Republic alone.

In April 1984, Warnke chose as an audience the Hamburg 'Afrika-Verein (Africa Society), the group representing the interests of West German Africa trade, which was then celebrating its 50th anniversary. Apart from the explicit commitment to a 'policy dialoguer as an "essential part of our development policy apparatus", the following sentences ought to be regarded as the central statement:

38 BMZ Informationen, No. 4/84, 30 May 1984, containing text of interview with 'Stuttgarter Nachrichten and 'Südwest Presse'; Rheinischer Merkur, 3 August 1984.

39 Rheinischer Merkur (Fn. 38).

40 BMZ Informationen (Fn. 38). 
". . as much as Africa may need development aid, it just as well needs more private enterprise cooperation, and this means direct investment... . What really is required today is the double-tracked approach of official aid and private cooperation. "41

This especially refers to medium-sized enterprise. The "Africa market" is "contested more than ever nowadays";

"the state has to perform the task of creating favourable conditions for entrepreneurial initiatives in future markets of the Third World ".$^{42}$

In the speech, the recently signed agreement between South Africa and Mozambique was also mentioned; this success of Pretoria's destabilization policy was praised as a "step in the right direction" by the Minister. ${ }^{43}$ By the way, the architect of this ostensible détente shortly afterwards personally attempted to reap the harvest of this policy in several European capitals.

In June 1984, South African Prime Minister Botha visited Bonn (appropriately 100 years after Transvaal's President Paul Krüger's visit to Berlin), accompanied by protest campaigns of the Federal Republic's Anti-Apartheid Movement. During this visit "discrete contacts" concerning economic and foreign policy problems "must have developed, but so far there has been no detailed information on this", as the quasi officious periodical 'Aussenpolitik' observed at the time. ${ }^{44}$ In the long run, greater dangers for Africa probably lie in an aspect that has hitherto attracted hardly any attention: the attempt of Botha to present South Africa as a "link between North and South", ${ }^{45}$ as that power which is best acquainted with the problems of the region's states, if not Africa in general. His statement that "We believe in economic cooperation, not charity ${ }^{46}$ was intended to sound well in these days of raid fatiguer, and tried to suggest the transfer of part of the West's 'development policy' to Pretoria. The racist oligarchy of the Cape would like to establish itself as the leading political and economic force at least of Southern Africa and hopes to be formally accepted as a 'proxy ' by the West. But the prospects to obtain such status are rapidly diminishing due to the mounting pressure the apartheid system has been facing ever since.

Whereas African affairs for long have been a topic for individual specialists or smaller groups only, the continent and its people over the last two-and-a-half years have become an area of concern for the broad public of the Federal Republic. Here, the image of Africa was not so much determined by historical reminiscences or foreign policy considerations, but rather by a film broadcast by the First Programme of German Television on Good Friday 1984. It was titled "Africa is Starving" and, following alarm reports by the Food and Agriculture Organization of the United Nations, called for aid in view of a "catastrophe of the century". Further appeals for donations were to follow,

43 Op. cit., p. 367.

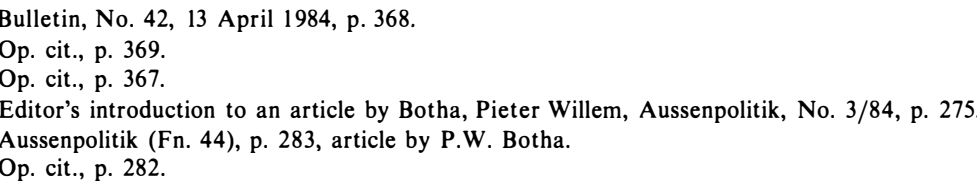


eventually culminating in the 'Day for Africar on January 23, 1985. A vast campaign, involving public figures from all walks of life as well as charity or sports organizations, succeeded in raising 110 mio. DM to assist in famine relief and rehabilitation. This was a positive manifestation of human spontaneity of many individuals. However, the stigmatising of Africa as the 'Hunger Continent', which has become more and more widespread, seems to be all the more problematical. The campaign did not mediate the insight into the necessity of structural changes in the industrial countries as well, but it simply thrived on an attitude of pity. So, whoever is the object of pity, whoever is merely benefitting from a paternalistic "Albert Schweitzer Model ", ${ }^{47}$ will not be regarded as a serious counterpart.

\section{Future Prospects}

For several years now, African countries have constituted the top of the list of bilateral ODA 'receivers' from the Federal Republic of Germany. ${ }^{48}$ So far, Africa has accounted for a total of more than 19 bio. DM. In 1986, $42 \%$ of funds for intergovernmental bilateral financial and technical rassistancer are earmarked for Africa $(29,6 \%$ for Africa south of the Sahara). As Foreign Affairs Minister Hans-Dietrich Genscher pointed out to the 13th United Nations General Assembly Special Session which was devoted to the icritical economic situation in Africar, "Africa will remain a focal point of this co-operation and benefit from increases in our development contributions". ${ }^{49}$ This would underline the theory of the author that Africa mainly counts for the Federal Republic of Germany in the context of its 'development cooperation' or raid, without an individual case having to offer any prospects of immediate profits or even long-term reflux of opening-up costs. Above it has already been explained that, apart from this, other political and economic factors also play a role. Before a summary can be formulated, a further factor must be examined whose importance can only be clearly seen in comparison with the days of the Berlin Conference: Whereas the European powers were then staging trade hunts and expansion on their own national behalf, the contemporary Western competitors are now coordinating their activities in certain areas and to a certain degree. With regard to development policy, the coordination of the idonors in the circle of the Development Assistance Committee (DAC) and the North-SouthGroup of the OECD (i. e., the organization of Western industrial countries) ought to be mentioned, as well as the coordinating mechanism of a number of Western sdonors known as CDA (Cooperation Development Africa), which is more directly geared to practice and loosely associated with the OECD. In talks on, say, the resumption of the

47 Expression coined by Bart-Williams, Gaston, afrika journal, No. 3--4/1982, p. 35.

48 Hofmeier, Rolf and Siegf ried Schultz, German Aid: Policy and Performance, in: Stokke, Olav (ed.), European Development Assistance. Vol. I, Tilburg and Oslo 1984, p. $219 \mathrm{f}$.

49 Speech delivered on 28 May 1986, United Nations document A/S-13/PV.3. 
Lomé Convention, the European Community as a single institution faces the African, Caribbean and Pacific states, and in the United Nations, the EEC states operate to a large degree as a unit. The Federal Republic of Germany co-determines the Western European policy or the general policy of the West; at the same time, it is strongly integrated in it - due to the recent past, much more than France or Great Britain. Recapitulating, one can state the following as regards its interests beyond the - tendentially slowly decreasing in importance - securing of raw materials:

1.

In the list of world trade nations, the Federal Republic of Germany occupies the second position; on the basis of its proportion in the international trade in industrial goods, it temporarily even lay ahead of Japan and the USA in first position. As a highly developed capitalist industrial state which is extremely dependent on the world market, it believes to have to rely to a special extent on the smooth functioning of if ree world trade and the existing world economic system. This explains its rigid attitude in the discussion on a New International Economic Order, but it also explains the special interest in the 'political stability of Africa and the warding off of 'foreign intervention' (i. e., of the East).

2.

Giving global system stabilization top priority enables various forms of action (which are also practised in different ways by the different political parties whilst in power) in individual cases: supporting distinct advocates of the rown way' (Tanzania), or supporting cleptocracies (Zaire). Those that most probably are not going to fall into the category of future markets (i. e., the majority of the African states), are to be integrated into the global system by welfare measures.

3.

This stability obsession also bears dangers. Wherever a favourable status quo seems to be jeopardized, geostrategists are prone to intervention. The readiness of the USA to intervene, which has grown in recent years, presents special risks to the German ally. And giving tacit or active encouragement to Botha-style 'peaceful' changer would as well involve long-term risks.

Those who reject state policy and the existing world economic system have more farreaching perspectives than the critics at the time of the Belrin Conference; it is precisely the global context that comes to the fore now. Liberation movements find sympathy among solidarity and church groups. Criticism reaches from reformist approaches through ethically founded positions to the fundamental opposition. The latter is not represented by the Social Democrats these days, but, certainly as far as its parliamentary manifestation is concerned, by the 'Greens', who entered the Bundestag in 1983. The 
system criticism of this new political force (which certainly contains many contradictions) has long passed the boundaries of the purely ecological concern.

The great bust-up ('Kladderadatsch - a term used by Bebel) is not more on the agenda now than it was a century ago. However, during the time of crisis, the internal social conflicts and distribution struggles have become more pronounced, and the climate has become cooler. Accordingly, the wind blowing from the 'North to the South has become rougher. This general meteorological situation continues also to affect Africa during the next few years. There is, however, also an opportunity in this dilemma: the possibility of finding an autonomous African answer to the challenges posed. 


\section{ABSTRACTS}

\section{Justice in a One-Party State: The Tanzanian Experience}

\section{By Umesh Kumar}

Many African states, after gaining independence from colonial rule, evolved into varieties of one-party polities. This paper delineates some basic features of African one-party régimes, with particular reference to the historical parentage constituted by national liberation movements which had come to the fore during the period of struggle for independence. Concentrating on Tanzania, the author describes some of the orthodox attempts to reconcile conceptually the predominance of one party with simultaneously perceived requirements for pluralist participation and judicial review; the uneasy practical coexistence of a supreme party and a judiciary theoretically charged with impartial review of executive acts and the authoritative exposition of the law; and, lastly, areas of improvement in order to prevent party paramountcy from submerging the influence of such agencies as parliament and the courts of law.

\section{Ideology and Strategy: German Africa Policy and Its Critics}

\section{By Volker Weyel}

The author reviews the creation, in the late nineteenth century, of the short-lived German colonial empire in context with the 1884 Berlin conference on Africa.

Contemporary and modern political and historical evaluations of the German colonial effort are discussed with particular reference to critical and apologetic attitudes towards colonisation and the influence on either of the 19th-century ideology of imperialism as a "civilising mission".

Modern sequels to past colonial ventures in present-day West German policy on development aid and international economic relations are critically assessed. 